\title{
Pathological study of Braken Fern ( Pteridium aquilinium ) toxicity in Rats
}

\author{
S. O. Youkhana \\ Coll. of Vet. Med./Unive. of Mosul
}

\begin{abstract}
A pathological study of braken fern ( Pteridium aquilinium) toxicity was conducted in rats. Twenty albino rats were randomly divided in to 4 groups. The first three groups were received diet containing $10 \%, 20 \%$ and $30 \%$ braken fern powder respectively. The fourth group was served as control. The experimental rats were sacrificed after one month. Gross and histopathological examination reveal lesions in many organs . Gross lesions revealed congestion of all internal organs, while the histopathological lesions were characterized by spongiosis , perivascular cuffing and astrocytosis in the brain. Swollen hepatocytes accompanied by vacuolation and fatty degeneration in the liver. Suppurative pneumonia with infiltration of inflammatory cells in the lungs. In intestine the villi were fused with proliferation of cryptal enterocytes. Interstitial nephritis associated by degenerative changes in the renal tubular epithelial cells . Acute cystitis with edematous lamina propria and neutrophilic infiltration were seen in urinary bladder. These lesions were more sever in the group 3 incomparism with group 1 and 2 . No lesions were observed in the control group .
\end{abstract}

Key words : Braken Fern, toxic plants, pathology, lesions .

\section{Introduction}

Braken fern ( Pteridium aquilinium ) is the fifth most distributed common weed species of ferns, found on exposed grassy lands in hills throughout the world ( 1 ). It is an ornamental, tufted, fast growing fern grow at borders, rocky areas, hills and also planted in pots for indoor decoration $(1,2)$ . Braken Fern has erect stiff fronds up to 1.5 $\mathrm{m}$. high but usually around $0.6-1 \mathrm{~m}$. The fronds are bright green and coiled when thy emerge, as they unfurl and expand they become harder and darker. Fully mature fronds are dark emerald green, the older fronds are smooth on top with fine hairs underneath and has an extensive spreading root system . It does not produce flowers or seeds, but instead they produce spores in bodies called " sori " which occur in a continuous line on the undersides of the fronds, the spores are minute $(3-5)$. Braken Fern is potentially poisonous to livestock ( 6 ), the most toxic part are the young green fronds. It's toxic effect was firstly recorded by Tophan in 1787 . Since then various toxic effects was reported in both animals and human beings. Braken Fern contain wide range of toxins like ( Tannin, Thiminase, Cyanogen glycosides , Isoquercetin , Pterosides , Pterosins , Fumeric acid, Succinic acid and Braxin ), these toxins have different biological activities which include mutagenic, clastogenic, carcinogenic , antithiaminic and histamine releasing factors $(7-9)$. However the toxic effect of fern toxins either in acute or chronic forms is well documented in nervous, alimentary, urinary systems and bone marrow of domestic as well as laboratory animals $(10,11)$. The most common effects include thiamine deficiency , acute hemorrhagic diseases, bright blindness, enzootic hematuria, intestinal and bladder carcinoma and thrombocytopaenia in horses, cattle, sheep , pigs and rodents (12-18). The object of the present work is to investigate the possible development of different patterns of lesions in many organs of rats which were fed with braken fern ( Pteridium aquilinium ). 


\section{Materials and Methods}

Twenty albino rats 30 days old weighting from $150-180 \mathrm{gm}$. were housed in standardized cages in a room maintained at $25 \mathrm{c}$ with 12 hours light dark cycle. The rats were divided in to 4 groups ( 5 rats of each ) . Rats were fed braken fern ( Pteridium aquilinium ) obtained from many nursery gardens in Mosul city (Fig.1). Braken fern freshly collected young fronds were cut in to small pieces $(1-2 \mathrm{~cm}$. ), dried and ground to a fine powder mixed with pelleted diet at different levels ( 10 , $20,30 \%$ by weight ). The first group was fed with standard diet containing $10 \%$ of dried braken fern powder. Group 2 received standard diet with $20 \%$ braken fern powder. Group 3 received standard diet with $30 \%$ braken fern powder . Group 4 was served as a control group and received only standardized pelleted diet only . The

rats in all groups were weighted, inspected and examined clinically every day and sacrificed after one month of the experiment. The rats in all groups were weighted and inspected clinically every day . The cage of each group was supplied with its specific weighted diet . After each day the remaining diet was weighted. The differences between the two weight values were the amount of diet consumed by the rats for that day. Post mortem examination was performed and tissue specimens were taken from brain, liver, lungs, intestine , kidneys and urinary bladder . Tissue samples were directly fixed in $10 \%$ formalin, dehydrated, embedded in paraffin wax and the tissue sections were stained with hematoxylin and eosin stain $(19,20)$.

\section{Results}

No significant differences in daily diet consumption of rats was detected. It appeared that all groups were ingested the diet provided for them . Two rats were died from the third group during the last week of the experiment . Depression was the only clinical sign observed in rats of the group 3 specially during the last week . At post mortem examination congestion of all internal organs was the most predominant lesion seen in rats of group 3 . Histopathological examination of the brain reveal spongiosis characterized by variably sized edema filled spaces within the white matter ( Fig. 2 ). The lesion involve both gray and white matter consist of aggregated microglial cells with neutrophilic infiltration ( Fig. 3 ) . Prominent perivascular cuffs of small mononuclear cells and macrophages with hypertrophy and proliferation of astrocytes were also seen. In liver swollen hepatocytes with vacuolation and cytoplasmic accumulation of fat was evident ( Fig. 4 ) . Furthermore congestion of sinusoids with infiltration of inflammatory cells (mainly lymphocytes and macrophages ) throughout the liver parenchyma . In lungs suppurative pneumonia characterized by abundant number of neutrophils, macrophages and cellular debris (purulent exudate) within the alveoli ( Fig. 5 ) . The alveolar septa were notably thickened by sever interstitial infiltration of neutrophils, intraalveolar exudation and inflammatory edema. The lesion was more diffusely distributed and involved all pulmonary lobes. In intestine the villi are denuded of epithelium and the crypts were dilated with hyperplasia ( Fig. 6 ) . Infiltration of lymphocytes and macrophages were seen in lamina propria . In kidneys interstitial nephritis associated by mixed inflammatory cell infiltration ( lymphocytes and macrophages ) which were randomly scattered and/or intensly localized throughout the interstitial tissue ( Fig. 7 ), with degeneration or even necrosis or both of tubular epithelial cells . Within the severely inflamed areas the profound tubular loss is usually accompanied by 
eventual replacement by fibrous tissue. In urinary bladder acute cystitis characterized by epithelial denudation. The lamina propria was intensely edematous accompanied by diffuse neutrophilic infiltration ( Fig. 8 ), superficial hyperemia and hemorrhage were evident . All the

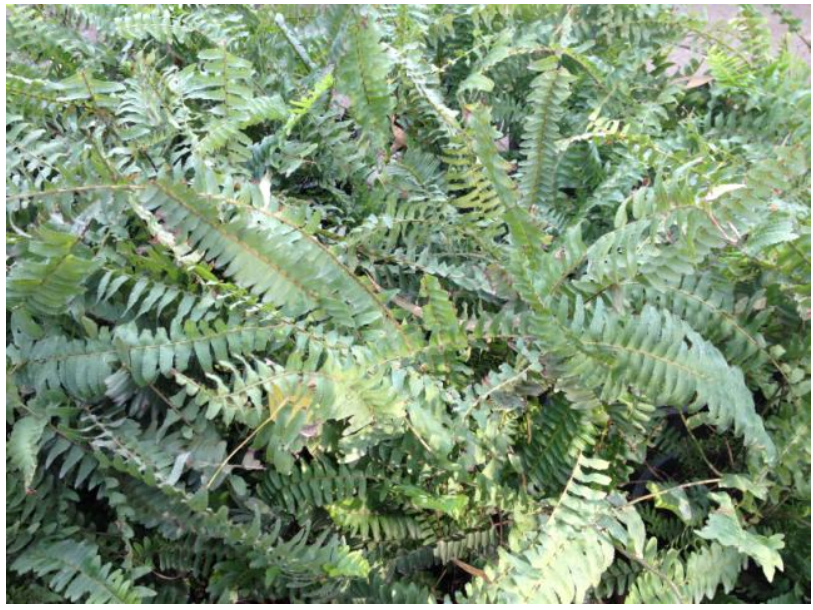

Fig (1): Braken fern ( Pteridium aquilinium ).

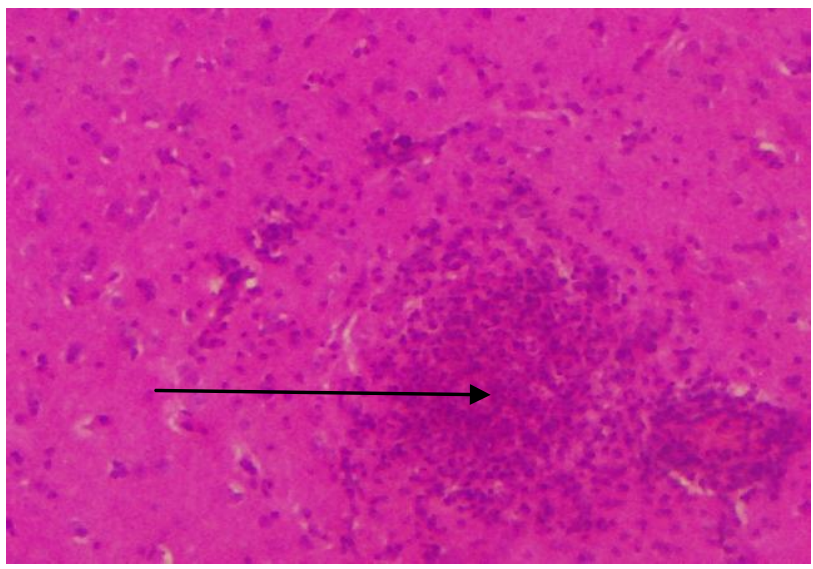

Fig (3): Aggregation of microglial cells and neutrophils in brain tissue (arrow). H \& E X 300 . above described gross and histopathological lesions appeared in rats of group 3 , which received $30 \%$ braken fern diet, while rats in groups 1 and 2 revealed mild lesions in the same organs. No lesions were observed in control group .

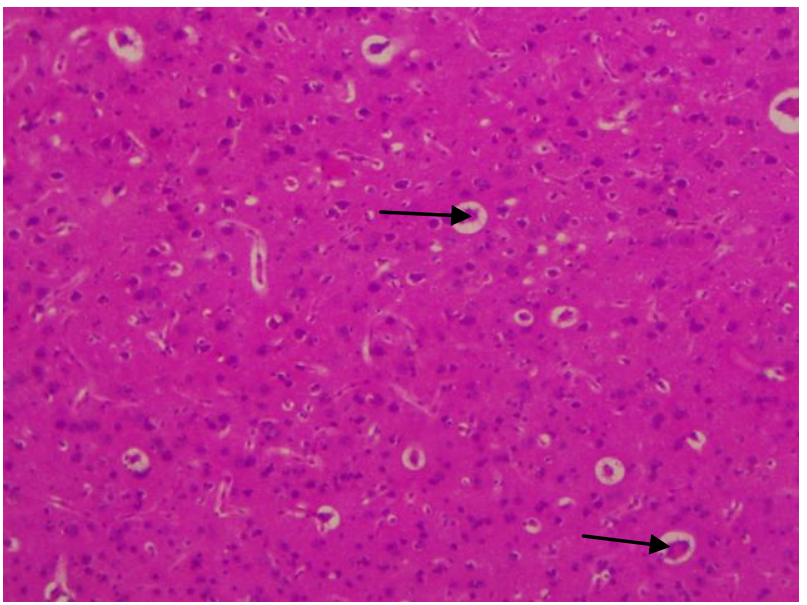

Fig (2): Spongiosis with vacuolation in the white matter of the brain (arrows) . H \& E X 300

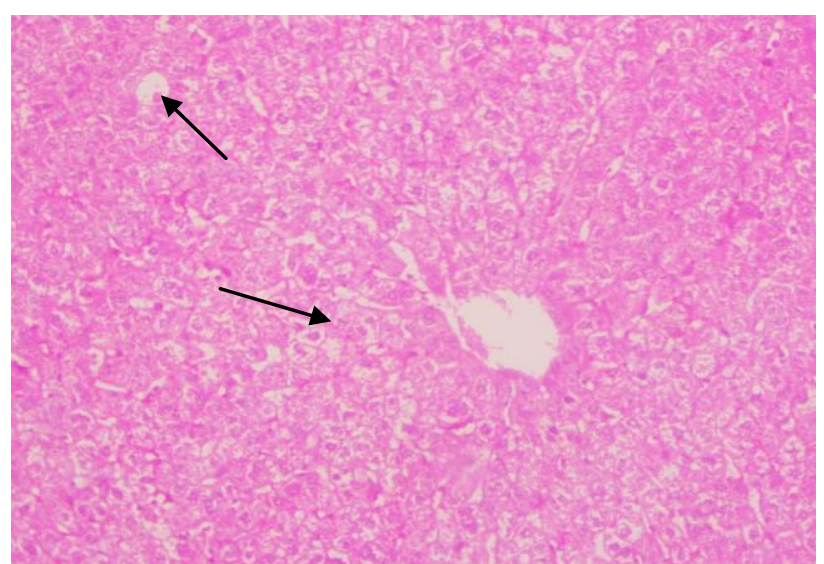

Fig (4): Swollen hepatocyts with vacuolation and fat degeneration (arrows). $\mathrm{H} \& \mathrm{E}$ X 300 . 


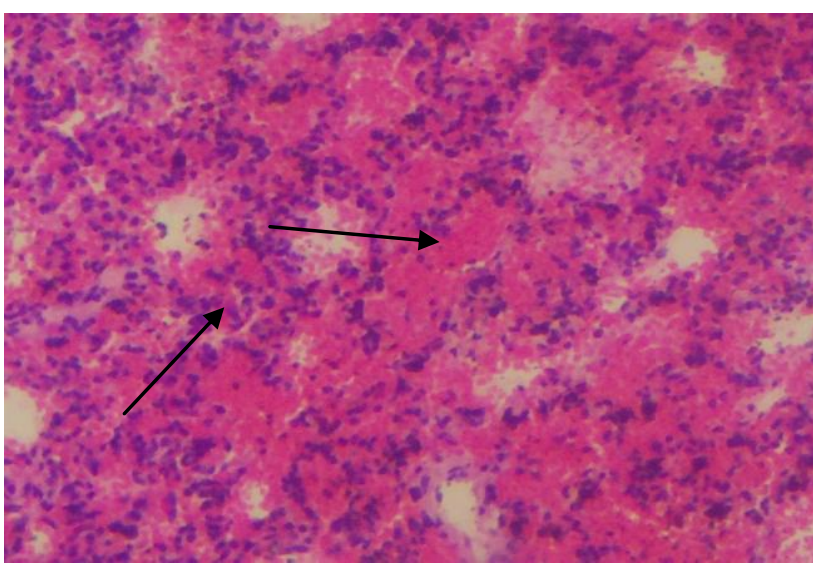

Fig (5): Suppurative pneumonia. purulent exudate filling The alveolar spaces (arrows). H \& E X 300 .

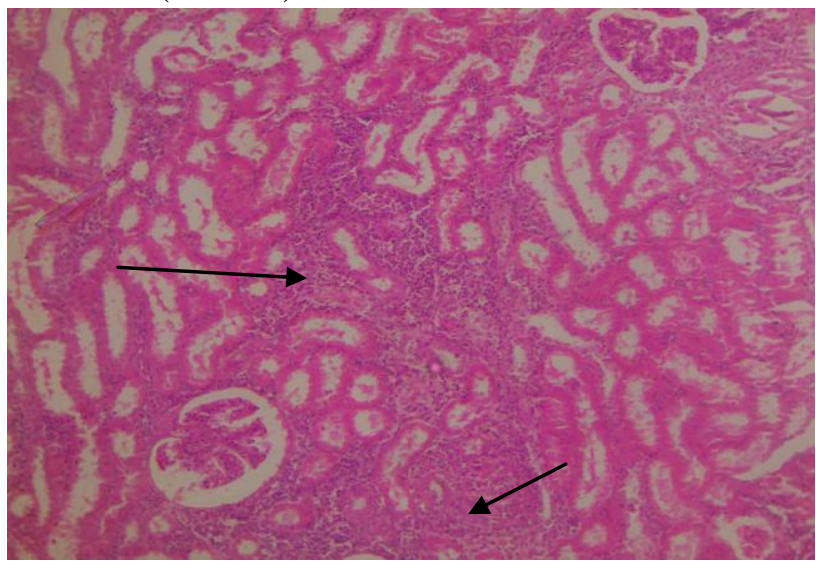

Fig(7):Interstitial nephritis. Infiltration of inflammatory cells mainly lymphocytes and macrophages in the interstitial renal tissue (arrows). H \& E X250.

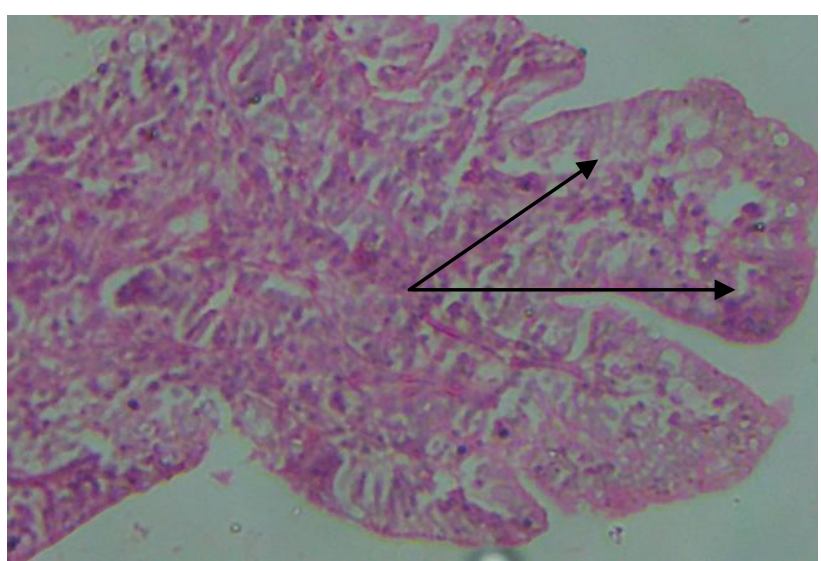

Fig (6): Dilation of intestinal crypt with hyperplasia (arrows). $\mathrm{H} \& \mathrm{E} \mathrm{X}$ 400

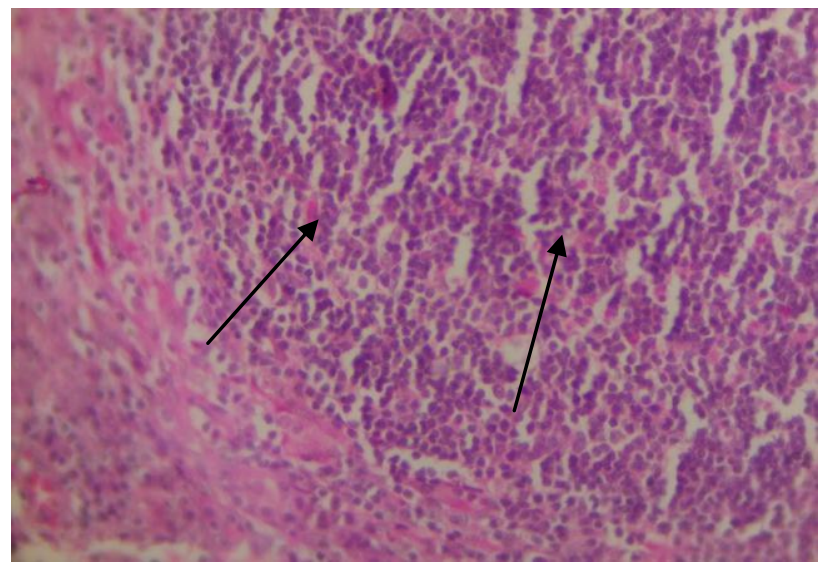

Fig (8): Acute cystitis . Neutrophilic infiltration in the lamina propria (arrows). H \& E X350

\section{Discussion}

Under natural conditions exposure of farm animals to braken fern occur during hanger , scarcity of fodder in drought, winter season, fodder contamination or by bedding materials (1). After ingestion braken fern produce well recognized lesions in various organs and tissues of the body . Plant toxins and poisons were classified according to the severity of their oral toxic effects in rats as extremely high, moderate, slight and those of low toxicity ( 21 ). The most poisonous substances of plant toxins are neurotoxins and cytotoxins . Neurotoxins affect important ion channels of neuronal cells either by activating or inactivating them permanently . Both actions will stop neuronal signal transduction and thus block the activity of central nervous system and neuromuscular signaling, which eventually leads to paralysis of both striated and smooth muscles of heart, lungs and skeleton. Cytotoxins interfere and disturb the cell function by inhibit each of the 
mitochondrial respiratory chain , ribosomal protein biosynthesis and deoxyribonucleic acid replication (22-24). The results of our research revealed that rats received braken fern in their diet developed histopathological changes in the brain like spongiosis, aggregation of microglial cells , perivascular cuffs and proliferation of astrocytes . These changes could be attributed to antithiamine effect of fern . the same results were recorded by others ( 10 ). To date many mechanisms were proposed to explain the nature and medullar pathways associated with thiamine deficiency and neuronal cell death, in addition that impairment of oxidative metabolism caused by thiamine deficiency accelerates microglial activation and result in neuronal cell loss ( 10 ). The cytotoxins in braken fern interfere with important cellular functions. An important target in this context are biomembranes, which control the import and export of metabolites and ions in the cell ( 25 ) . Cell membrane permeability and integrity can be severely disturbed leading to accumulation of fluid and fat in the cell, in addition to inducing inflammatory response which were clearly obvious in our study in the liver cells revealing swollen hepatocytes with vacuolation and cytoplasmic accumulation of fat associated with infiltration of inflammatory cells. In lungs hematogenous cytotoxins of fern cause damage to alveolar epithelium and injury of vascular

\section{Acknowledgment}

The author would like to acknowledge all staff members of laboratory animal house and histopathological unit in college of veterinary medicine, university of Mosul

\section{References}

1- Somvanshi R, Ravisankar R. Recent advances in braken fern toxin research . Natural Product Radiance ,2004; 3(4):304-308.

2- Thomson JA, Smith RT. Braken fern biology and management. endothelium ( $26-28)$. In our study suppurative pneumonia begin with injury to either type 1 pneumonocytes or alveolar capillary endothelium, which provokes a disruption of the blood-air barrier and a subsequent exudation of plasma proteins into the alveolar space. This leakage of proteinaceous fluid into alveolar space ( intraalveolar exudation) together with inflammatory edema and neutrophilic accumulation in the alveoli and intersitium cause thickening of the alveolar wall . These changes were in agreement with others ( 26 ). In intestine sloughing of the villous cells results in shortening and sometimes fusion of the villi .The crypts where dilated with proliferation of cryptal enterocytes. The same cytotoxic effects were seen in kidneys . Interstitial nephritis associated by inflammatory cell infiltration with degeneration or even necrosis or both of epithelial cells lining renal tubules . The vascular damage of urinary bladder predispose to hemorrhage and leakage of fibrin accompanied by mucosal ulceration with neutrophilic infiltration ( 15 ). These changes were obvious in our study in acute cystitis characterized by hyperemic and edematous mucosa with neutrophilic infiltration. In conclusion $30 \%$ braken fern contained diet fed to rats cause well defined histopathological lesions in various tissues of the body due to it's neorotoxic and cytotoxic effects

for their great support and providing all facilities required for establishing this research work .
Occasional publication, AIAS (NSW), Sydney, 1999; 62-67.
3 - Marrs RH, Johnson SW, LeDuc MG. Control of braken and restoration of heath land VI. The response of braken fronds to 18 years of 
continued braken control. J App Eco , 2000; 35 : 479-490.

4 - Hartig K, Beck E. The braken fern dilemma in the andes of the southern Ecuador. Ecotropica , $2003 ; 9: 3-13$.

5 - McWhirter L, Kemp H . Braken fern industry and investment. Prime

facts , 2010; $730: 1-5$.

6- Long HC . Plants poisonous to livestock - University Press , Cambridge, UK , 1997 ; 119-120 .

7- Fenwick GR. Braken ( Pteridium aquilinium ) toxic effect and toxic constituents . J Sci. Food and Agriculture, 1989; 46 :147-173.

8- Wang C, Chiu C, Pamukcu A, Bryan G. Identification of carcinogenic tannin isolated from braken fern ( Pteridium aquilinium ). JNCL J Natl cancer inst , 1975 ; 56 (1) : 3336.

9- Hirono I, Asios S, Yamaji T, Mori H, Yamada K, Niwa H, Ojika $M$, Wakamatsu K, Kijoshi H, Niiyama $\mathrm{K}$, Uosaki Y. Carcinogenecity in rats of ptaquiloside isolated from braken fern. Gnn, 1984, 75 : 833836.

10 - Farajzadeh H ,Tehrani A, Amirarfaei Y, Pourata A, Mansoub H, Tehrani

Mohammad M. Pathological studies on the incidence of braken fern

induced encephalomalacia in rat. Annals of biological research, 2011; 2 (4): 386-392.

11- Ravisankar R, Somvansh R, Tandon SK, Naik A. Behavioural and pathological studies on laboratory rats fed with crude extract of braken fern. Indian veterinary research institute, article year, 2005; 12 (2) :125-128

12- Pamukcu AM, Price JM, Bryan GT . Naturally occurring and braken fern induced bovine urinary bladder tumors . Vet Pathol, 1976; 13: $110-122$.
13- Bringuier $\mathrm{P}$, Berger $\mathrm{N}$, Perrin $\mathrm{P}$, Devonec M. Braken fern induced bladder tumor in guinea pigs . Am J Path ,1995; 147 (3) :858-868 .

14- Ushijima J, Matsukawa K, Yuasa A, Okada M. Toxicities of braken fern in gunia pigs Jpn J Vet Sci, 1983; $45: 593-602$.

15- Rao D, Joshi H, Kummar M, Singh G . Pathological studies on braken fern ( Pteridium aquilinium) induced hematuria in calves and rats. Ind $\mathbf{J}$ Ani Sci , 1990; 60 (6) :654-656.

16- Ravisankar r, Somvanshi R, Ajit N. Behavioural and pathological studies on laboratory rats fed with crude extract of braken fern. Indian Veterinary Research Institute , 2005; (12) 2:125-128 .

17- Latorre AO, CAniceiro BD, Wysocki HL, Haraguchi M, Gardner DR, Gorniak SL .Selenium reverses ( Pteridium aquilinium ) induced immunotoxic effects. Food and Chemical Toxicology ,2011; (49) 2 :464-470.

18 - Hannam DA. Braken poisoning in farm animals with special reference to the North York Moors, 1986; 133138. In Smith RT, Taylor JA, (eds.). Braken Ecology, land use and control technology.

19 - Luna LG. Manual of histological staining methods of the armed forces institute of pathology division. McGraw - Hill Book Company. New York, 1986 ; 12 17 .

20- John D, Bancroft MG . Theory and practical histological techniques . $6^{\text {th }}$. ed . Churchill Livingston , 2008 ; 133-145.

21- Wink M . Mode of action and toxicology of plant toxins and poisonous plants . Heidelberg university, Institute of Pharmacy and Molecular biotechnology , 
Heidelberg, Germany, 2009 ; 93112 .

22- Wink M . Interference of alkaloids with neuroreceptors and ion channels. Bioactive Natural Products , 2000 ; 11: 93-129.

23- Wink M . Molecular modes of action of cytotoxins from DNA intercalation , spindle poisoning, topoisomerase inhibition to apoptosis and multiple drug resistance, G. Cordell, ed . Elsevier, 2007 ; 64 : 1-48.

24- Wink M, Schmeller T, Latz-Broning B. Modes of action of allelochemical alkaloids : Interaction with neuroreceptors, DNA and other molecular targets. J Chemical Ecology , 1998; 24:1881-1937 .
25- Alberts B, Johnson A, Lewis J, Raff M, Roberts K, Walter P . Molecular biology of the cell . $5^{\text {th }}$ ed . Garland Science, NY, 2008; 95-97

26- Delclaux C, Azoulay E .Inflammatory response to infectious pulmonary Injury . Eur Respir J Suppl , 2003 ; $42: 10-14$.

27- Jubb KVF, Kennedy PC, Palmer N . Pathology of domestic animals $.5^{\text {th }}$ . ed . New York, Academic Press, $2006 ; 242$.

28- Donald McGavin M, Zachary James F. Pathologic bases of veterinary disease . $4^{\text {th }}$ ed. Elsevier, 2007 ; 101-143 .

\title{
دراسة مرضية لسمية نبات السرخس(Pteridium aquilinium) في الجرذان
}

\author{
صموئيل اوشعنا يوخنا \\ كلية الطب البيطري/جامعة الموصل \\ الخلاصة
}

اجريت دراسة مرضية لسمية نبات السرخس في الجرذان حيث تم تقسيم عشرون من الجرذان البيضاء بشكل عشو ائي الى وائى

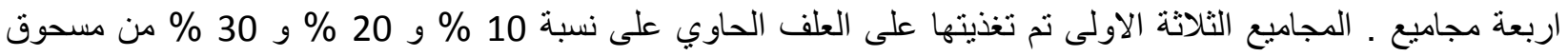

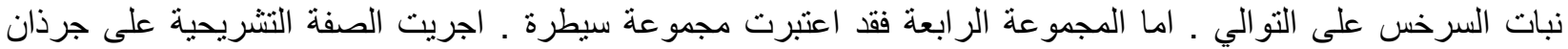

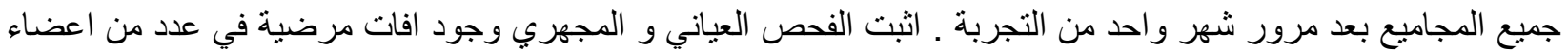

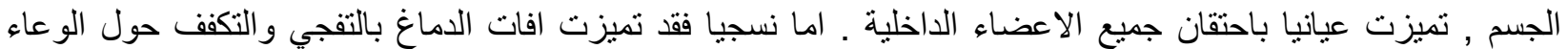

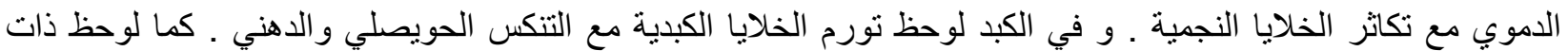

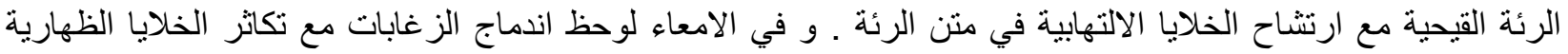

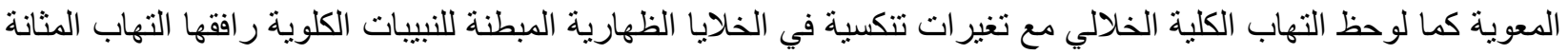

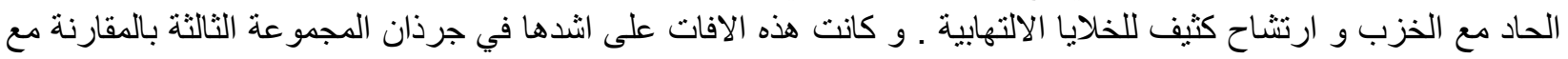

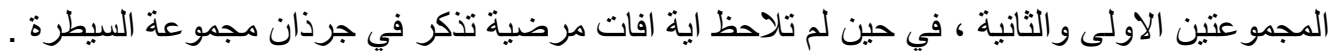

